less, but other contributing bodies, we are glad to see, continue their support as usual. The Senate has wisely decided to retain its Publication Fund for works of science and learning on the scale which funds allow. Grants amounting to $£ 1,583$ were made last session. Among the benefactions we notice $£ 25,000$ in seven annual instalments for rebuilding at Queen Mary College from an anonymous donor, $£ 2,660$ from the Duke of Bedford for a fellowship in medical radiology at the Middlesex Hospital Medical School, a donation of $£ 250$ for one year from the Iraq Petroleum Company converted to twice as much for seven years, and $£ 250$ a year for seven years from the Gaekwar of Baroda to make a lectureship in Marathi a full-time post.

\section{Pioneering in Educational Radio}

Dr. C. G. Аввот, secretary of the Smithsonian Institution, has announced that a period of four years of pioneering in educational radio was completed on June 9 by the Institution. The object was to increase and diffuse knowledge among the people generally. The title of the popular series of broadcasts was "The World is Yours". In addition to science, the main theme of the series, the broadcasts dealt with exploration, history, engineering and invention, and art. A few recent titles will show the wide diversity of subjects treated: "Stars in the Sky", "The Indians who met Columbus", "Earthquakes", "Flying in Safety", "Cortez, the Conquistador", "Pompeii Lives Again", "Radium", "Dinosaurs". Since the programme was inaugurated on June 7, 1936, "The World is Yours" has expanded from its original 27 stations to a network of 82 stations covering the United States. The most recent, and the highest tribute paid to the series came last February when a leading American radio audience research service announced that the Smithsonian dramatizations received the highest rating of all serial programmes on the air. This followed from an analytical survey of all the programmes given on all networks.

To promote further this 'increase and diffusion of knowledge', the educational value of these programmes is preserved by the Educational Radio Script Exchange, U.S. Office of Education, Federal Security Agency. Hundreds of school and civic groups have used these scripts for production by radio and over sound systems. Another now radio service began last October with the inauguration of The World is Yours Magazine. Dedicated to the popular theme, "catch it by radio-fix it in print", these weekly magazines present a wide variety of articles by Smithsonian curators on historical, scientific, and engineering subjects for lay readers and schools. Some of the features of these new 'doors' to knowledge are dramatic scenes from the script, selected bibliographies for further study, recent news from the Smithsonian, and illustrations from rare drawings and photographs in the files of the Institution. Nearly 100,000 copies of these have been sold in the first half-year, the sales being on a non-profit basis. "The World is Yours" is produced for the Smithsonian Institution by the U.S.
Office of Education with the co-operation of the National Broadcasting Company and with the assistance of the Work Projects Administration.

\section{Regulation of the Upper Mississippi}

Thr Mississippi and Missouri, together, form the longest river system in the world, extending to a length of 4,502 miles. Above its junction with the Missouri, the Mississippi has a length of 1,170 miles and drains an area of 171,500 square miles. In an article in Engineering of July 19, a description is given of that part of the Upper Mississippi lying between the Missouri and the town of Minneapolis in Minnesota, 659 miles long. In 1907, a projoct was adopted for the regulation and improvement of the river from Missouri to Minneapolis in order to provide a 6-ft. channel at times of minimum flow. The work carried out consisted mainly of dredging and the construction of wing dams to restrict the width of the low-water channel. Twenty years later, the U.S. Congress directed that a survey of the river should be taken with the view of providing a lowwater channel with a depth of nine feet. The project involved the construction of a series of locks and dams, and fairly extensive dredging. The work was completed last March at a cost of 170 million dollars. Twenty-five dams were required, and special Tainter and Roller gates were used for regulating the flow. The gates of later construction are designed so that they can be lowered several feet below the normal level of the pool, allowing even heavy ice to pass over the top.

The principal traffic on the Upper Mississippi River consists of fleets of barges, usually pushed by steamers of the stern-wheel or twin-screw type. The barges range in length from $100 \mathrm{ft}$. to $300 \mathrm{ft}$. and in beam from $24 \mathrm{ft}$. to $48 \mathrm{ft}$. The capacity varies from 500 to 3,000 tons. A tow of barges, practically filling one of the $110 \mathrm{ft}$. by $600 \mathrm{ft}$. locks, carries $6,000-8,000$ tons of goods, and requires a 1,000 h.-p. steamer for its propulsion. In operation, it is possible to pass about fifty fleets of barges through the locks in twenty-four hours. The fifty-two over-bridges between Minneapolis and the Missouri River in general provide vertical clearances above high water in excess of $50 \mathrm{ft}$. and horizontal clearances varying from $106 \mathrm{ft}$. to $710 \mathrm{ft}$. Traffic on the river consists mainly of coal, petrol, fuel oil, steel-products and grain. The total tonnage handled between Minneapolis and the Missouri in 1936 was 2,300,000 tons.

\section{Strengths of Indian Timbers}

EvEr since the inauguration of the Imperial Forest Institute at Dehra Dun, one of its branches has been engaged in testing out the strength and properties of indigenous timbers. Many timbers hitherto neglected or regarded as useless for practical commercial purposes are now coming under the tests of the research investigators. The Timber Testing Section of the Forest Research Institute has been studying the strength properties of Indian timbers for many years now, and more than 215 consignments of timber have been tested up to date. In Indian Forest Records, 